\title{
Expansion of Cashew Cultivation and its Environmental and Economic Impacts on Guinea-Bissau
}

\author{
A expansão do cultivo do caju e seus impactos ambientais e econômicos na Guiné-Bissau
}

Abdulai Ismail Seca $^{1}$ (D), Henrique dos Santos Pereira ${ }^{1}$ (D), Suzy Cristina Predroza da Silva ${ }^{1}$ (D)

\section{A B S T RA C T}

Guinea-Bissau has recently become the fifth largest producer in the world of Cashew Nut Shell (CNS) and the product accounts for $90 \%$ of the country's total exports. The objective of this study was to analyze the expansion of cashew cultivation and its environmental and economic impacts on the country, from the perspective of sustainable development. In the methodology, correlational statistical analyses were used, based on multiple regression, correlation, and linear regression techniques. To qualify the empirical results based on the historical series of secondary data, an online questionnaire was applied to nine experts to assess the impacts of sector-specific public policies on Cashew Nut Shell Production (CNSP) and Cashew Nut Shell Export (CNSE). Finally, geoprocessing techniques were used to identify the deforestation trends in the country (2002-2018). As main results, it was verified that from 2000 to 2015 , the CNSE accounted for an average of $8.9 \%$ of the country's GDP. As for environmental impacts, it was found that between 2002 and 2012, the country's deforestation was explained by the CNSP $\left(p<0.001\right.$ and $\left.R^{2}=0.91\right)$, whereas between 2013 and 2017, although positively associated, the relationship was not significant. Geoprocessed data on vegetation cover indicate that from 2002 to 2018, accumulated deforestation was intensified mainly in the southern and northern regions of the country. To make full use of cashew, a greater effort is needed from the Government and the productive sectors, which would allow the sustainable development of the sector and a substantial increase in the production of other crops.

Keywords: cashew nuts; deforestation; export; agricultural product; forest conversion; West Africa.

\section{RES U M 0}

A Guiné-Bissau tornou-se recentemente o quinto maior produtor mundial de Castanha de Caju com Casca (CCC) e o produto corresponde à $90 \%$ das exportações totais do país. O objetivo deste estudo foi analisar a expansão do cultivo de caju e seus impactos ambientais e econômicos no país, sob a perspectiva do desenvolvimento sustentável. $\mathrm{Na}$ metodologia, utilizaram-se análises estatísticas correlacionais, baseadas em técnicas de regressão múltipla, correlação e regressão linear. Para qualificar os resultados empíricos baseados nas séries históricas dos dados secundários, foi aplicado um questionário online com nove especialistas para avaliação dos impactos das políticas públicas setoriais da Produção de Castanha de Caju com Casca (PCCC) e Exportação de Castanha de Caju com Casca (ECCC). Por fim, utilizaram-se técnicas de geoprocessamento para identificar a evolução do desmatamento no país (2002-2018). Como principais resultados verificou-se que de 2000 a 2015, a ECCC teve contribuição média de $8,9 \%$ no PIB. Quanto aos impactos ambientais, constatou-se que entre 2002 e 2012, o desmatamento do país é explicado pela PCCC ( $<<0,001$ e $R^{2}=0,91$ ), já entre 2013 e 2017, embora positivamente associado, a relação não foi significativa. Os dados geoprocessados da cobertura vegetal indicam que de 2002 a 2018, o desmatamento acumulado foi intensificado principalmente nas regiões sul e norte do país. Para que haja o aproveitamento integral do caju, é necessário um maior esforço por parte do governo e dos setores produtivos, o que permitiria o desenvolvimento sustentável do setor e um aumento substancial de produção de outras culturas.

Palavras-chave: castanha de caju; desmatamento; exportação; produto agrícola; conversão de florestas; África Ocidental.

\footnotetext{
${ }^{1}$ Universidade Federal do Amazonas - Manaus (AM), Brazil. discente.ufg.br

Conflicts of interest: the authors declare that there are no conflicts of interest.

Funding: Conselho Nacional de Desenvolvimento Científico e Tecnológico (CNPq).

Received on: 10/31/2020. Accepted on: 04/12/2021.

https://doi.org/10.5327/Z21769478950
}

Correspondence address: Abdulai Ismail Seca - Rua Luiz Otávio, 4 - Petrópolis - CEP: 69067-680 - Manaus (AM), Brazil. E-mail: abdulaiseca@

This is an open access article distributed under the terms of the Creative Commons license. 


\section{Introduction}

In recent years, cashew has become the main agricultural product of Guinea-Bissau. The export of cashew nut shells (CNS) varies from $85 \%$ to $90 \%$ of the country's total exports, with India as the main buyer country (FMI, 2015). In view of the growing international demand for CNS and the government's incentive, the cultivation of cashew (Anacardium occidentale Lynn.) became the main economic activity of the rural families that compose most of the population. The production is manually carried out, and the effort to increase productivity only occurs by expanding the agricultural land area used to grow cashews.

Most of the displacement of land use occurred from high-income countries to low-income countries (Weinzettel et al., 2013), with the recent expansion of export-oriented commodity crops causing largescale deforestation in the humid tropics (Rudel et al., 2009). From 2000 to $2011,40 \%$ of tropical deforestation came from the production of agricultural commodities (Henders et al., 2015). The proportion of underlying deforestation as a share of export-oriented agricultural products has doubled during this period to more than 33\% (Henders et al., 2015). Brazil and Indonesia were responsible for $61 \%$ of the global tropical deforestation from 2000 to 2005, largely associated with the expansion of soybean production, pastures for cattle, and oil palm plantations (Defries et al., 2010).

South America, Southeast Asia, and Sub-Saharan Africa are experiencing the fastest rates of agricultural land expansion (Ordway et al., 2017). Moreover, Ordway et al. (2017) reports that in Cameroon, recent foreign investment in agriculture and a government boost to increase cocoa and oil palm production provided an opportunity to assess whether large-scale industrial monoculture is expanding into forested areas. In Guinea-Bissau, the cashew crop has been gaining importance for the export of CNS.

Guinea-Bissau has consolidated its status as the fifth largest producer of CNS in the world and the second largest producer and exporter country on the African continent. About a third of the country's agricultural land is occupied by cashew trees (PER, 2019). Guinea-Bissau manages to export almost $100 \%$ of its annual production (FAOSTAT, 2020).

Therefore, the challenges addressed in this study consisted of the analysis of the following questions: what are the environmental impacts that occur or may occur due to increased production? What are the factors that influence the dynamics of CNS production and export?

To answer these questions, some objectives were defined. The overall objective of the research is to analyze the expansion of cashew cultivation and its environmental and economic impacts on Guinea-Bissau focusing on sustainable development. Specific objectives are defined as follows: to determine which variables influenced the production dynamics and export in Guinea-Bissau; to assess the impacts of Guinea-Bissau's sector-specific public policies on cashew nut production and export; and to verify spatial patterns of land-use changes associated with the expansion of cashew cultivation over vegetation areas.

\section{Literature review}

Guinea-Bissau is located in West Africa and has a population of 1.8 million (World Bank, 2019). It borders the Atlantic Ocean, as observed in Figure 1.

Guinea-Bissau borders Senegal (North), the Republic of Guinea (East and South), and the Atlantic Ocean (West). The country's economy heavily depends on the primary sector. According to data from the Observatory of Economic Complexity (OEC), in 2017 the main products exported from the country were: coconuts, peanuts and cashew nuts, and frozen fish (OEC, 2020). Agriculture, forestry, fishing, and hunting are the dominant economic activities in the country, accounting directly and indirectly for about $46.9 \%$ of the gross domestic product (GDP) in 2011 and 39.7\% in 2016 (Arvanitis et al., 2017). Cashew nuts are the country's main agricultural product and their exports range from $85 \%$ to $90 \%$ of the country's total exports, with a strong concentration of exports to India and Vietnam (FMI, 2015).

Cashew is a perennial tree species belonging to the Anacardiaceae family and to the Anacardium genus (Catarino et al., 2015; FAO, 2020). It is mainly grown in tropical countries, especially in Brazil, Vietnam, India and the Ivory Coast (Dendena and Corsi, 2014; Elakkiya et al., 2017), Nigeria, Indonesia, Philippines and Benin (FAOSTAT, 2020), and Guinea-Bissau (Catarino et al., 2015; Cateia et al., 2018). Brazil, India, and Vietnam are the world's largest processors.

Cashew production in Guinea-Bissau is manually carried out, and the effort to increase productivity only occurs by expanding the agricultural land area used to grow cashews. Production grows not due to the development of new technologies, but by increasing the replacement of native forest or areas used to grow other crops. In the study entitled "Drivers of deforestation and degradation for 28 tropical conservation landscapes," it was noted that rice was the agricultural commodity most often cited as driver for forest change in tropical landscapes, followed by rubber and cassava (Jayathilake et al., 2020). In Tanzania, small-scale cultivation of corn, sesame, cowpea, and sorghum are the main immediate drivers of deforestation (Doggart, 2020).

In Guinea-Bissau, deforestation has been increasing due to agricultural production. Changes in the forest of northern Guinea-Bissau and southern Senegal occurred as a result of the human land use predominantly associated with agricultural activities such as charcoal production, cashew trees and collection of wood for construction and firewood for household needs (Cabral and Costa, 2017).

In the study entitled "Determinants of Guinea-Bissau cashew exports (1986-2011): an analysis under the Bergstrand gravity model," the reported results of the panel data model (OLS-pooled) suggest that the flow of cashew nut exports is positively related to the exchange rate and gross and per capita incomes, which is consistent with the theoretical assumptions of gravitational models and with the seminal studies of economic literature with the application of these models (Cateia et al., 2018). 


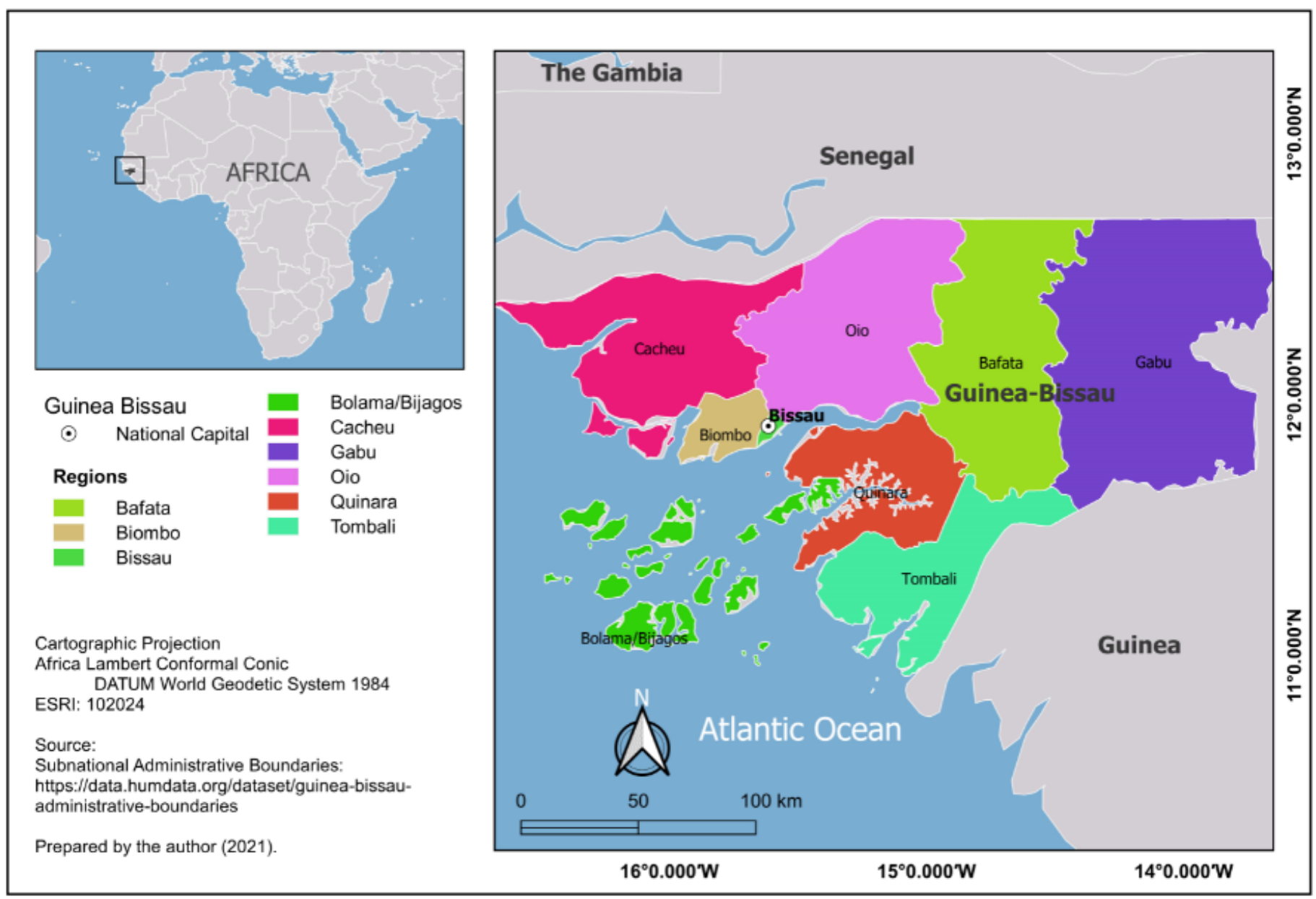

Figure 1 - Administrative regions of Guinea-Bissau.

\section{Materials and Methods}

This study was carried out in Guinea-Bissau, a country in West Africa, covering the period from 1990 to 2018, with secondary data and official documents available from the following websites and organizations: BCEAO, FAOSTAT, IMF, WORLD BANK.

The methodological procedures of this research are organized according to the objectives of the study, which are: Overall goal: analysis of the expansion of cashew cultivation and its environmental and economic impacts on Guinea-Bissau with focus on sustainable development. For this purpose, the statistical model of correlation and simple regression was used to assess environmental impacts, and for economic impacts, analysis of statistical data was used to represent the percentage of Cashew Nut Shell Export (CNSE) in the country's GDP. As specific objectives:

- to determine which factors influence the dynamics of Cashew Nut Shell Production (CNSP) and CNSE in Guinea-Bissau. For this purpose, multiple regression analysis was used;
- to assess the impacts of Guinea-Bissau's sector-specific public policies on the CNSP and CNSE, a questionnaire was prepared using Google Forms, sent to nine specialists in the area, and their answers enabled to assess the impacts of public policies on the sectors of CNSP and CNSE;

- to verify spatial patterns of land use changes associated with the expansion of cashew cultivation replacing areas of native vegetation. For this third and last objective, geoprocessing techniques were used to ascertain the possible substitution of forest by cashew cultivation.

Multiple linear regression analysis

The technique of multivariate data analysis consisted of the construction and validation of linear regression models. This model serves to understand the behavior of the independent variables in question.

To this end, the following steps were completed:

1. specification of the objectives for the regression analysis, which includes the selection of the dependent and independent variables; 
2. determining the sample size;

3. the assumptions inherent in regression analysis (normality, linearity, homogeneity).

It is also important to verify if there is multicollinearity between the variables.

For Dormann et al. (2013), in the construction of these models, some assumptions must be verified, especially if there is dependence between the independent variables. If these dependencies are strong (when the value is greater than 10) there may be multicollinearity, causing effects on the estimates of the regression coefficients and on the general applicability of the estimated model.

\section{Variables tested for the CNSP model}

The sample size of the time series of variables depends on the existence of data available on websites and official documents. In this study, it was established as a goal to construct a historical series with secondary data covering the period from 1990 to 2017 ( Table 1). The year 1990 was chosen because this was the year when the country began to have significant global participation as a CNS producer.

Variables for the CNSP model were selected based on a bibliographic and documentary review of topics related to temporal and spatial dynamics in agricultural production and productivity.

\section{CNS Price}

In the study entitled "Cashew nut production in Tanzania: constraints and progress through integrated crop management," it was noted that the increase in producer prices and marketing were efficient tools to attract increased production from farmers. In this context, farmers have recovered large areas of previously abandoned cashew

Table 1 - Main variables that influence CNSP.

\begin{tabular}{|l|c|c|c|}
\hline Variable & Type & $\begin{array}{c}\text { Unit of } \\
\text { Measurement }\end{array}$ & Data Source \\
\hline CNSP & Dependent $(\mathrm{Y})$ & Tonne $(\mathrm{t})$ & FAOSTAT \\
\hline National Price & Independent $\left(\mathrm{X}_{1}\right)$ & Dollar $(\$)$ & BCEAO \\
\hline Rice Production & Independent $\left(\mathrm{X}_{2}\right)$ & Tonne $(\mathrm{t})$ & INE/BCEAO \\
\hline $\begin{array}{l}\text { Climate } \\
\text { (Precipitation) }\end{array}$ & Independent $\left(\mathrm{X}_{3}\right)$ & Millimeter $(\mathrm{mm})$ & World Bank \\
\hline $\begin{array}{l}\text { Climate } \\
\text { (Temperature })\end{array}$ & Independent $\left(\mathrm{X}_{4}\right)$ & Degree Celsius $\left({ }^{\circ} \mathrm{C}\right)$ & World Bank \\
\hline $\begin{array}{l}\text { Mancarra } \\
\text { Production } \\
\text { (Peanut) }\end{array}$ & Independent $\left(\mathrm{X}_{5}\right)$ & Tonne $(\mathrm{t})$ & BCEAO \\
\hline
\end{tabular}

CNSP: Cashew Nut Shell Production; FAO: Food and Agriculture Organization of the United Nations; INE: National Institute of Statistics; BCEAO: Central Bank of West African States; FAOSTAT: Global Statistical Database of FAO - it provides free access to food and agriculture data. farms and are currently improving their cultivation methods by adopting disease control measures and planting improved materials on new farms (Martin et al., 1997).

\section{Climate change and cashew production}

The distribution and behavior of precipitation are basic factors for the planning of agricultural activities such as: definition of dates for soil preparation and sowing, sizing of spillways, rain networks, structures to protect against erosion and floods, and preparation of additional irrigation projects. Taking these aspects into account, the volume of rain that falls in a region can be considered as a factor that determines the agricultural activity to be developed in such location (Danfá et al., 2009).

Both temperature and precipitation are important variables for agricultural production in the tropics; overall, the irregularity of rain, high temperatures, and violent winds are the main climate changes indicated by cashew producers in Benin as a factor of low agricultural productivity (Bello et al., 2017).

In order to choose the climate variable that influences cashew productivity, the following data were tested: average monthly temperature and average monthly precipitation, with the sample size from 1990 to 2016. The correlation between CNSP and variable monthly average temperature from January to December was tested; subsequently, the correlation between CNSP and average monthly precipitation from January to December was calculated; and finally, the correlation between CNSP and the climate variables (temperature and precipitation) that have a greater correlation with annual CNS production was estimated. In this case, this estimate enabled to choose the independent variables that have a strong positive correlation with the CNSP, to test in the final model of CNSP.

\section{The main agricultural products: rice and peanuts}

Cashew has not always been the Guinea-Bissau's main agricultural and export product. In the colonial period, other products were important to the country's economy such as peanuts and rice (Balde, 2008). Peanut production reached its peak in the period of colonization, when farmers were encouraged to produce for export (Medina, 2008). Once natural resources and production factors, such land and labor, are finite and limited, this study verifies if changes in rice or peanut production could influence the CNSP. In the event that there are years of increases in these products, this influences the SCNP.

\section{Variables tested for the CNSE model}

Variables for the CNSE model were selected based on a bibliographic review (scientific articles, theses and dissertations, etc.) related to the topic, collected by Google scholar and magazines available from the CAPES system. The tested variables are presented in Table 2. The sample sizes of the variables vary according to the data available 
Table 2 - Main variables that influence CNSE.

\begin{tabular}{|c|c|c|c|}
\hline Variable & Type & $\begin{array}{l}\text { Unit of } \\
\text { measurement }\end{array}$ & Data Source \\
\hline CNSE & Dependent (Y) & Tonne (t) & $\begin{array}{c}\text { INE/BCEAO/ } \\
\text { FAO }\end{array}$ \\
\hline $\begin{array}{l}\text { World } \\
\text { Production }\end{array}$ & Independent $\left(\mathrm{X}_{1}\right)$ & Tonne (t) & FAOSTAT \\
\hline Tax on CNSE & Independent $\left(\mathrm{X}_{2}\right)$ & Dollar (\$) & $\begin{array}{l}\text { MCGUINEA- } \\
\text { BISSAU }\end{array}$ \\
\hline $\begin{array}{l}\text { Exchange } \\
\text { rate }\end{array}$ & Independent $\left(\mathrm{X}_{3}\right)$ & Dollar (\$) & BCEAO \\
\hline Instability & & $\begin{array}{c}\text { Dummy variable } \\
(1 \text { or } 0)\end{array}$ & Literature Review \\
\hline
\end{tabular}

CNSE: Cashew Nuts Shell Export); MCGUINEA-BISSAU: Ministry of Commerce of Guinea-Bissau; FAO: Food and Agriculture Organization of the United Nations ; INE: National Institute of Statistics; BCEAO: Central Bank of West African States; FAOSTAT: Global Statistical Database of FAO - it provides free access to food and agriculture data.

from the websites and official documents. A historical series of secondary data from 1990 to 2017 was used for this analysis. The year 1990 was chosen as the base year because it was the period when the country began to have significant global participation as an exporter of CNS.

\section{World production}

There is a long tradition of quantifying the impact of agricultural trade distortions on the world market, especially in the context of multilateral trade. A small impact on the world market price can lead to substantial changes in production and trade (FAO, 2014). This variable enabled to understand whether, in years when there was an increase in the world production, such increase had an impact on the country's total exports.

Taxes

Tax collection is revenue from resources obtained from the collection of taxes (i.e., taxes, fees, and contributions). According to Anselmo (2013, p. 7), "it is every compulsory cash payment, in currency, or whose value can be expressed therein, that does not constitute a penalty for an illegal act, established by law and charged through fully earmarked administrative activity." Taxation is one of the powerful economic instruments that societies have to implement their public policies and influence the allocation of resources.

\section{Exchange rate}

The exchange rate has a great impact on a country's exports; when a country's currency is devalued, the country tends to export more and vice versa. The role of the exchange rate in international trade is essen- tial because its variations can induce changes in the prices of domestic goods in relation to foreign goods (Silva et al., 2016). The final tested variable is instability; Guinea-Bissau is a country that has gone through several decades of political instability.

\section{Political instability}

Political instability is one of the major problems for the economic development of any society. Since its independence, Guinea-Bissau has been facing difficulties with political instability, which creates barriers to productivity and economic growth. The literature has shown that violent conflicts, such as civil wars and other forms of instability, have led to the death of people, weaknesses of institutions, and economic losses such as the destruction of physical capital (Samate, 2018).

Expansion of cashew cultivation and its environmental impacts

After Guinea-Bissau independence in 1974, and specifically after the adoption of structural adjustment measures (mid-1980s), CNS exports increased and farmers gradually began to plant cashew trees for CNS marketing and to guarantee their possession of land. They adopted a process of an "agricultural frontier" in which all crop fields are no longer left fallow; instead, cashews are grown together with food crops for three to four years, until the field becomes an orchard, when the cashew tree canopy closes and a new area must be cut and burned, thereby increasing deforestation in a linear manner (Temudo and Santos, 2017).

Thus, a correlation and regression model was used to assess the impact of the CNSP on the accumulated deforestation of the country's native forest (ADNF). With the sample size of the available data, from the years 2002 to 2017, a series was built with the FAOSTAT database (Food and Agriculture Organization of the United Nations) for CNSP data (FAOSTAT, 2020), and with Deforestation Statistics for ADNF (Deforestation Statistics, 2020).

\section{Analysis of economic impacts}

Previous studies have shown the importance of CNSP in Guinea-Bissau, with its production destined almost exclusively for export. For this analysis, descriptive statistics and graphs were used. The economic impact was estimated in terms of the percentage of CNSE in the country's GDP, with sample size from 2000 to 2015.

The GDP database was converted into US dollars, having been collected through the World Bank website and for CNSE in XOF (Guinea-Bissau currency). The database of the last variable was obtained from the Central Bank of Guinea-Bissau (BCEAO, 2019). CNSE values were first converted from XOF to euro (EUR) (fixed value of 655 $\mathrm{XOF}=1$ EUR), because the historical series of the XOF exchange to the US dollar was not found. Subsequently, the amounts in EUR were converted to the US dollar, through an exchange rate series (Banco de Portugal, 2020). 
Data collection methods: questionnaire

A questionnaire was prepared using the Google Forms application, designed for specialists working in the deforestation sector, CNSP, CNSE, and in the cashew value chain in Guinea-Bissau. The selection and recruitment of respondents were accomplished through the snowball sampling technique. Snowball is the type of non-probabilistic sampling in which chains of reference are used (Vinuto, 2014).

The e-mails of some interviewees were acquired through studies performed by them and previously published. As inclusion criteria, it was determined that the participants should reside in Guinea-Bissau, have research and studies related to the topic or have investigated the topics of the present study, be over 18 years of age, without distinction regarding sex, religion, and ethnicity. As for the exclusion criteria, it was determined that the participant should not be unemployed for more than one year and have some type of illness that would prevent them from answering the questions. Before sending the questionnaires, these questions were investigated with the individuals invited to participate in the study. This research was approved by the Human Research Ethics Committee (CEP) of Universidade Federal do Amazonas, Brazil.

To assess the impacts of Guinea-Bissau's sector-specific public policies on the CNSP and its exports, nine (9) experts on the topic were interviewed, who work in different sectors: teaching and research institutions, government agencies, and non-governmental organizations. Seven (7) of the interviewees were men and two (2) were women, most (6) of the interviewees lived in Guinea-Bissau and the others, in Portugal. As for age, six (6) of the interviewees were over 50 years of age and have been working in the CNS sector for between 3 and 15 years.

The completion of the questionnaire was preceded by the mandatory reading and acceptance of the Informed Consent Form. A questionnaire form was created with closed-ended questions, such as "What is the main cause of deforestation in Guinea-Bissau?", to which respondents have options for answers, as well as open-ended questions, such as "How do you see the cashew trade and its obstacles?", to which respondents described their opinions. The questionnaire form was structured in three sections: identification, questions about deforestation, and questions about public policy in the cashew sector. The responses enabled to assess the impacts of the country's public policies on the CNS production and export sectors.

\section{Geoprocessing techniques}

Geoprocessing is an important tool of environmental sciences applied tothe conservation of natural resources (Novo and Ponzoni, 2001). Based on the principles and methods of geoprocessing, there are some studies that have sought to describe the relations between the causes of deforestation in some regions of Guinea-Bissau. As in the study conducted by Temudo and Abrantes (2014), the authors of the present article also concluded, in the exploratory stage of this research, that when using remote sensing technologies, the spatial and spectral resolution of
Landsat satellite images and the tree classifiers do not allow for detecting the spectral difference between coverage by native forests and that by cashew orchards, making it impossible to calculate precise rates of deforestation, forest degradation, and recent changes in land use.

To compensate for this deficiency, data were collected from georeferenced cashew cultivation locations, in collaboration with the National Statistics Institute of Guinea-Bissau (INE), from 44 cashew orchards in the South and East of the country, using the Global Positioning System (GPS), in flat geographical coordinates - UTM $28 \mathrm{~N}$.

These data obtained in 2017 were initially tabulated in electronic spreadsheets, with identification of the name of the owners of the cashew orchards and the geographic coordinates in UTM. The country's spatial data (shapefiles) were provided by the website "The Humanitarian Data Exchange" and the QGIS program allowed the mapping of cashew cultivation areas, based on data collected in the field. The incidence and location of cashew orchards were compared with the spatial deforestation trends in the country.

For the analysis of deforestation, the Global Forest Change database (Hansen_GFC 2001-2018) was used (Global Forest Change, 2013). In the QGIS software, the image was vectored from year to year, then the vectors for each year of deforestation were redesigned (for EPSG projection: 102022 Africa Albers Equal Area Conic) to perform the area calculation in hectares.

\section{Results and Discussion}

\section{Multiple regression analysis for CNSP}

Taking into consideration the performed research, data analysis, and the bibliographic review, the variables that influenced the CNSP were peanut production, rice production, temperature in July, November and April, and finally the national price of CNS. For this study, variables were tested before defining the final model to be tested. The multicollinearity values were: Peanut $(\mathrm{Pe})=2.71$; National Price $(\mathrm{Pr})$ $=1.22$; April temperature $(\mathrm{TApr})=1.45$; July temperature $(\mathrm{TJl})=2.28$; November temperature $(\mathrm{TNv})=1.18$; Rice $(\mathrm{Ri})=1.88$. It was noted that there is no multicollinearity between the variables because they have correlation values below $10 \%$.

According to the analysis made with the R software, the stepAIC test of the multiple regression model eliminated the national price variable, as it has no impact on the CNSP and has an individual significance value of 0.63 , which is a value greater than 0.05 (Table 3 ). The stepAIC test is used to simplify the model without greatly affecting its performance (Li et al., 2017).

According to analysis with the $\mathrm{R}$ software, the overall significance value of the variables is lower than 0.05 . The significant variables were Peanut production (Am); Production of rice (Ar); and Temperature for the month of July (TJl). With a 95\% confidence interval, it is possible to understand the impact of each variable on the CNSP, with $\mathrm{R}^{2}$ equal to $93.8 \%$, where $38.2 \%$ are explained by the increase in peanut production 
Table 3 - Summary of the variables that influence CNSP in Guinea-Bissau (1999 to 2017).

\begin{tabular}{|l|c|c|c|c|}
\hline & Estimate & Standard Error & $T$ & $\mathbf{p}(>|t|)$ \\
\hline Intercept & 2.76 & 2.42 & 1.14 & 0.27 \\
\hline Pe & 0.004 & 0.001 & 2.85 & 0.01 \\
\hline TApr & 0.23 & 0.04 & 1.43 & 0.17 \\
\hline TJl & 0.23 & 0.05 & 4.01 & 0.001 \\
\hline Ri & 0.002 & 0.0004 & 4.94 & 0.0003 \\
\hline
\end{tabular}

Pe: Peanut production; TApr: April average temperature; TJl: July average temperature; Ri: Annual rice production.

(Am), $35.2 \%$ by the increase of rice (Ar) production, and $25.3 \%$ by the temperature in July (TJl). The adjusted $\mathrm{R}^{2}$ value equals 0.91 . In this case, this means that $91 \%$ of the CNSP is explained by the variation in independent variables such as Am, Ar, TJl, TApr. The TApr variable was not significant in the final model.

Corroborating a study conducted by Samate (2018), it was found that there was an increase in the production of the main agricultural products, namely peanut and rice production. Such growth occurs in parallel with the increase in CNS production, and this increase in production is likely in line with the cumulative increase in deforestation in the native forest, generating loss of biodiversity and ecological changes. For CNSE there are independent variables that influence the country's exports. The main purpose of the CNSP is to export.

\section{Multiple regression analysis of CNSE}

The variables that influenced the CNSE were as follows: World Production of CNS (WP), Taxes on CNSE (TX), Exchange Rate (ER) and Political Instability (Inst) (Table 4 ). In this second model, the multicollinearity values are: world production $(\mathrm{WP})=3.09$; taxes on CNSE (TX) $=1.76$; exchange rates $(\mathrm{ER})=3.49$; Instability (Inst.) $=1.06$. Based on these values, it was concluded that there is no multicollinearity of the variables, as these values are lower than 10 (Dormann et al., 2013).

In this study, the stepAIC test of the multiple regression model excluded the Political Instability variable in the final regression model, as this variable has an individual significance value of 0.67 , which is a value greater than 0.05 .

The overall significance value of the variables is lower than 0.05 , which is lower than 0.5. The significant variables were PM and TX (Table 4). The TC showed an individual significance level lower than 0.05 ; in this model the exchange rate variation is not significant for CNSE. According to analysis with the R software, with a 95\% confidence interval, it is noted that $\mathrm{R}^{2}$ is equal to $92.74 \%$; it is noteworthy that about $65.5 \%$ of the variation in CNSE is explained by the PM, $19.8 \%$ is from TX and $14.6 \%$ is associated with TC. In this study, the adjusted $\mathrm{R}^{2}$ value is 0.91 ; therefore, it can be inferred that $91 \%$ of CNSE is explained by the variation of independent variables such as PM, TX, and TC.
Table 4 - Summary of variables that influenced the Guinea-Bissau CNSE (1999-2017).

\begin{tabular}{|l|c|c|c|c|}
\hline & Estimate & Standard Error & $t$ & $\mathrm{p}(>|t|)$ \\
\hline Intercept & $1.03 \times 10^{1}$ & $2.88 \times 10^{-1}$ & 35.65 & $6.44 \times 10^{-16}$ \\
\hline WP & $4.16 \times 10^{-7}$ & $5.05 \times 10^{-8}$ & 8.23 & $6.01 \times 10^{-7}$ \\
\hline TX & $5.79 \times 10^{-4}$ & $2.04 \times 10^{-4}$ & 2.84 & 0.01 \\
\hline ER & $-3.91 \times 10^{-1}$ & $2.38 \times 10^{-1}$ & -1.64 & 0.12 \\
\hline
\end{tabular}

WP: World Production; TX: Export taxes; ER: Exchange rate.

Over the years, on average, the government of Guinea-Bissau has been raising taxes on CNSE. The result of the regression analysis suggests that this increase in taxes did not negatively affect exports. It is understood that the government sees an opportunity for greater collection of tax revenue, considering that such increases do not affect the performance of the country's export balance.

The exchange rate is an economic variable used by governments to encourage or discourage exports and imports of goods and services. It is also a variable that impacts on exports, as it affects the price of the final product. In the study by Cateia et al. (2018), the reported results of the panel data model (OLS-pooled) suggest, on the one hand, that the flow of cashew nut exports is positively related to the exchange rate and gross and per capita incomes, which is consistent with the theoretical assumptions of gravitational models and with the seminal studies of economic literature on the application of these models. However, in this study, it was observed that TC is a variable; despite having an $\mathrm{R}^{2}$ value of $14.6 \%$, it presented an individual significance value of 0.12 , which is an indication that its variation would not have affected the CNSE.

CNS is a product that has not yet reached its maximum production peak worldwide, that is, the demand is still greater than the supply. This is verified by the increase in the production of its almond, whose demand is high as a product for final consumption and also as an intermediate good for the production of other byproducts. Its economic value has been encouraging an increase in production, through the intensification of land use.

\section{Environmental impacts}

For environmental impacts, according to the statistical test performed in the $\mathrm{R}$ software, there is a $3.88 \times 10^{-6}$ significance between deforestation of native forest (DNF) and CNSP for data recorded between the years 2002 and 2017. The correlation is positive in the period, with $\mathrm{R}^{2}$ equal to 0.89 ; in other words, it seems that $89 \%$ of the deforestation of the native forest in those years can be attributed to the expansion of CNSP (Figure 2).

Based on the graph, it is possible to observe that in the period between 2002 and 2012 the DNF was consistently followed by the production of CNS. This evidence corroborates the idea that the expansion of CNSP was one of the main causes of deforestation in these years. 


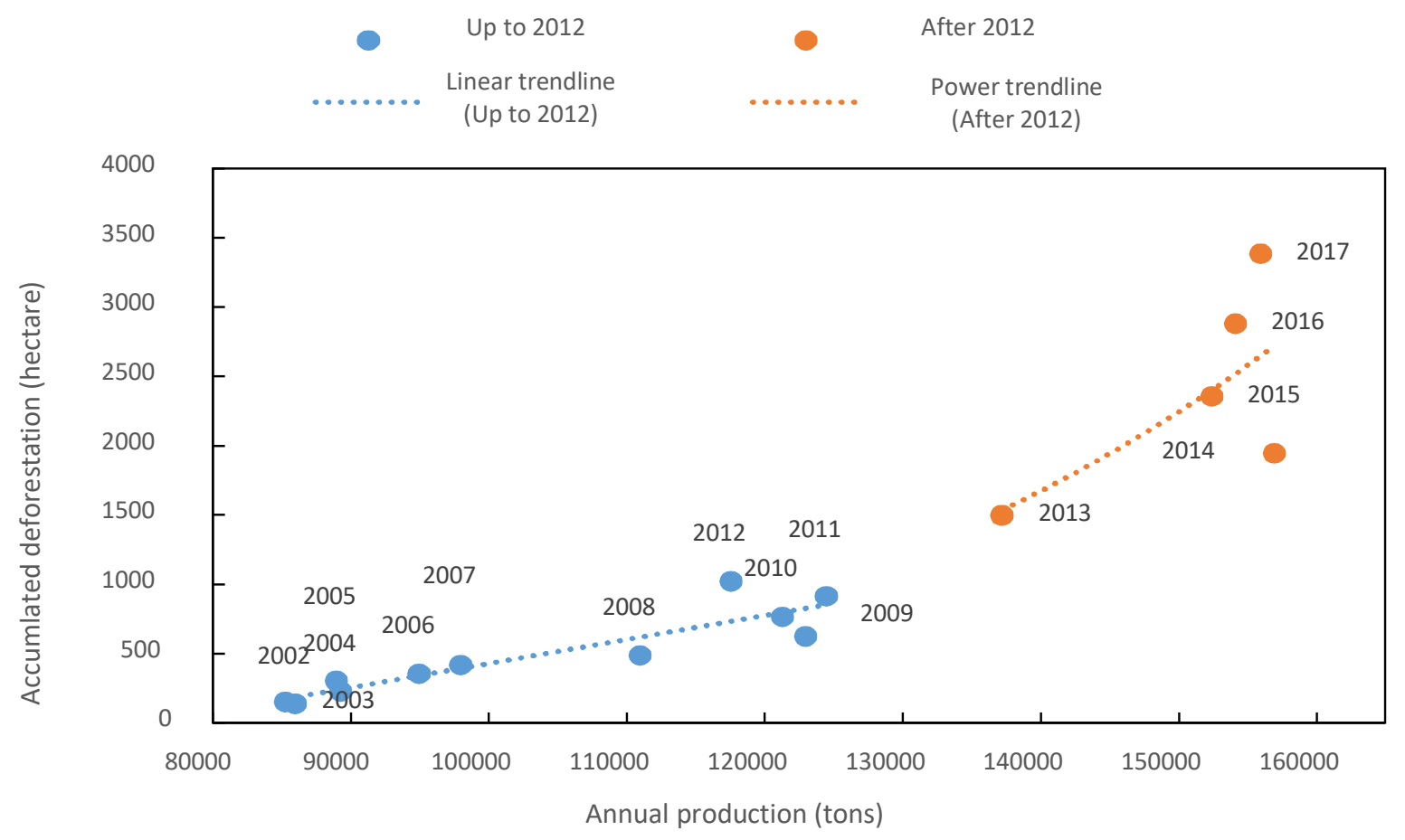

Figure 2 - CNSP and Accumulated Deforestation of Native Forest (ADNF), 2002 to 2017, Guinea-Bissau.

Source: Prepared by the authors based on data from FAOSTAT (2020) and Deforestation Statistics (2020).

In this interval, linear regression was highly significant $\left(\mathrm{p}=8.62 \times 10^{-5}\right.$; $\left.\mathrm{R}^{2}=0.91\right)$.

However, in the period from 2013 to 2017 , there is a discrepancy between CNSP and accumulated DNF (i.e., ADNF). Deforestation has become much more accelerated in this period, and it seems that it did not follow the variation in the CNSP. Thus, the value of $\mathrm{R}^{2}$ is only 0.66 in this range. Although the CNSP can still explain most of the recent deforestation, the result of statistical testing for the 2013 to 2017 interval resulted in a value of $\mathrm{p}=0.21$, that is, not significant.

Thus, there may be other factors that boosted the DNF such as illegal logging and increased rice and peanut production. Although changes in soil cover are a consequence of human land use predominantly associated with agricultural activities, these changes are also associated with the production of charcoal and the extraction of wood, for construction purposes, and firewood for domestic use (Cabral and Costa, 2017).

Motta (2002) demonstrated that deforestation can indirectly increase the probability of floods, and thus cause flood damage. Hence, the value of this loss would consist in an environmental cost associated with deforestation. Forests have a strong connection with the resource base that sustains life on the planet (water, air, soil, fauna, etc.), and have a direct influence on climate, particularly with respect to environmental temperature and humidity (Muteia, 2014). Guinea-Bissau is one of the poorest countries in the world. According to a study performed by the United Nations Development Programme
(UNDP, 2019), the Human Development Index (HDI) of Guinea-Bissau in 2018 was 0.46 , which places the country in the low development category, in position No. 178 of the 189 countries and territories listed.

\section{Economic impacts}

The CNSP is essentially destined for exports, thus contributing to the composition of the national GDP. In the analyzed period (from 2000 to 2015), there was an increase in GDP of about $183.1 \%$, with a minimum value of approximately USD 370.2 million and a maximum of USD 1.1 billion (Figure 3). CNSE also showed a growth of approximately $79.4 \%$ in the period, with a minimum value of USD 36.8 million and a maximum of USD 125.6 million (Figure 3).

As the main results, the authors found that from 2000 to 2015, CNSE accounted for an average of $8.9 \%$ of the GDP. In 2000, the CNSE share of GDP was 18.9\%; in 2003, it was about 7.7\%. From 2003 to 2014 , the CNSE share of GDP account for an average of approximately $6.6 \%$. In 2015, however, there was a recovery, when CNSE reached an even more significant percentage, achieving the level of $12.0 \%$.

This CNSE share of GDP is significant, considering that there are several other sources of income that constitute the composition of a country's GDP such as: investments, government spending, household consumption, and exports minus imports, in which CNS plays a major role. Cashew production directly and indirectly employs about $80 \%$ of the Guinea-Bissau population. Cashew nuts represent more than $90 \%$ 


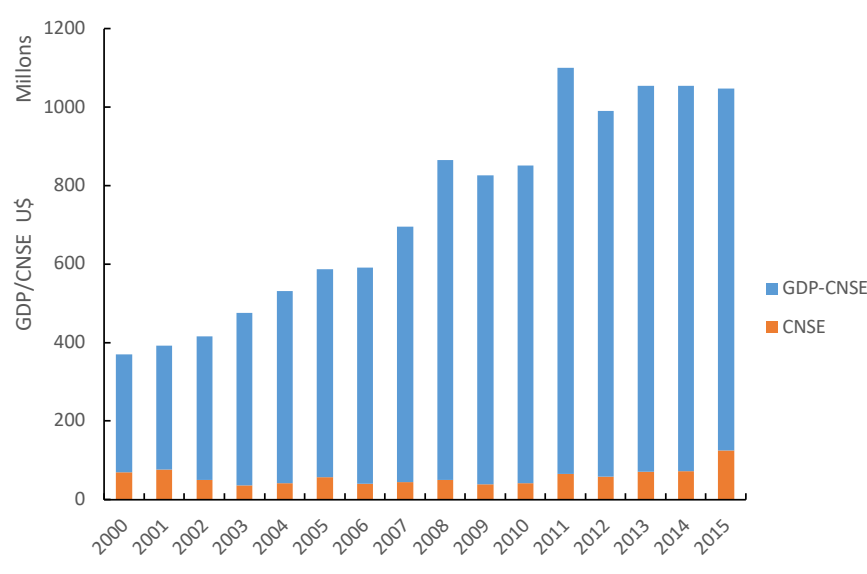

Figure 3 - CNSE as a share of GDP, 2000 to 2015, Guinea-Bissau.

Source: Prepared by the authors based on data from the World Bank (2019) and BCEAO (2019).

of the country's export earnings and still constitute the largest source of cash income (MEPIR, 2012; FMI, 2017).

This economic activity has at least four macroeconomic impacts:

- the commercialization of CNS injects liquidity for producers, intermediaries and exporters;

- it affects the price levels of other goods and services, due to the high propensity of economic actors to consume;

- it is the main source of foreign exchange earnings due to exports;

- it is an important source of tax revenue, due to the taxes collected from the commercialization of CNS, until it is exported (FMI, 2017).

Due to the increasing exodus of young people, older producers consider fruit growing as an old-age insurance, because, in the words of one of them, "even though the children are all gone, we can continue to eat from its income" (free translated by the authors) (Temudo, 2009). They also choose the product because it has relatively lower production costs than other products. The development of the sector benefits most of the population, either directly or indirectly. Thus, some studies show that, due to the economic importance of CNS, this process has been encouraging the deforestation of native forests in the country.

It is worth considering that this intensification of the exploitation of forest resources and changes in land use with loss of native forest cover may not result in improvements in the living conditions of the population. Thus, it is necessary to implement effective public policies for sustainable development in the country.

Impacts of sector-specific public policies on CNSP and CNSE in Guinea-Bissau

The investment structure of rural cashew properties entirely consists of the families' own capital. The absence of financing for invest- ments in rural areas prevents producers from expanding their production capacities through the adoption of the best recommended practices for production to increase productivity (Samate, 2018).

Among the nine respondents, five believe that it is the non-governmental institutions (NGOs) that most contribute to investments for growth and development in the cashew sector. Only one specialist mentioned public institutions as being of major importance. Three respondents do not know how to answer to this matter. Thus, it is perceived that there is no confidence in the action of government public policies that may result in the necessary investments in different areas that would allow the growth and sustainable development of the cashew sector.

According to the responses of the interviewees (respondents), there is a consensus on the need for diversifying agricultural production, with monoculture being perceived as risky for the country's economic sustainability. This was evident in the remarks of one of the interviewees: "Because of the fluctuations in the international price of cashew, the diversification of agricultural production enables to anticipate the country's dependence on cashew production."

Therefore, the specialist perceives the influence of variations in the international market on the country's economy and that the diversification of agricultural production would allow the country to minimize its dependence on cashew production.

Regarding CNSE, there is also a consensus on the need for export diversification, with export monopoly being perceived as risky for the country's economic sustainability, as evidenced in the remarks of one of the interviewees: "The exports of other agricultural products, such as mangoes, peanuts, as well as fishery products, is essential to promote the economic return derived from primary activities."

Export diversification would contribute to reducing negative impacts in the event of a drop in the price of cashew in the international market.

In Guinea-Bissau, only $1 \%$ of CNS is transformed into cashew nuts (CN) through processing, whereas in countries such as India and Vietnam, CNS processing is greater than their production. These countries import CNS from countries such as Guinea-Bissau, then process and export it in the form of $\mathrm{CN}$, which has greater added value. Thus, such places earn greater profitability, which contributes to the GDP growth of those countries (ANCA, 2013).

For the vertical integration of the country's economy, investments from public and private sectors are essential to create an efficient and sustainable industrial segment for CNS processing and the full use of cashews as well as other agricultural crops. Thus, such investments would allow the country to have a larger share of the world's cashew market. Steps must be taken to attract foreign investment in the cashew processing sector. The attempts made by domestic investors demonstrated the challenge associated with processing; they did not obtain good results in the sector, considering the high cost of local financing.

The value chain requires an integrated approach to develop the sector, complemented by activities to promote diversification. This in- 
tegrated approach is critical for addressing food security issues, increasing farmers' resilience to external shocks, encouraging rural communities to participate in the work along the value chain, developing new sustainable opportunities in agriculture, and informing future structural changes in policies. Without public policies, everything indicates that Guinea-Bissau has been suffering from intense forest deforestation due to human activities.

Spatial patterns of changes in land use associated with the expansion of cashew cultivation: replacing areas of native vegetation

Previous studies show the intensification of deforestation for economic purposes in Guinea-Bissau. Changes that have occurred in the soil of Guinea-Bissau are a consequence of the human land use predominantly associated with agricultural activities, urban and infrastructure development, production of charcoal, cashew trees, and collection of wood for construction and firewood for domestic needs (Cabral and Costa, 2017). In this study, it can be observed that until 2001 , land occupation occurred on a small scale and more slowly when compared with subsequent years. During this period, the regions of Cacheu, Oio and Bafafá were the most affected, whereas the South of the country, where there is better conservation of biodiversity, and an eastern part (Gabu) were the least affected areas. It is noteworthy that the location assessed in this study in Gabu and Tombali, where the reference cashews are located, did not appear to be intensely deforested at that time (Figure 4).

The occupation of land use has been significantly increasing in all regions of the country, but mainly in the southern region, where the border with the Republic of Guinea is located, and the northern region that corresponds to the border with the Republic of Senegal. The main causes of deforestation may be associated with an increase in population. From 1990 to 2018, there was a population growth of about $92 \%$ in the country, with an average annual growth of about 2\% based on the year 1990 (World Bank, 2020), which somewhat boosts agricultural production and illegal timber trade, especially in the border regions.

The study performed by Temudo and Cabral (2017) indicated evidence that the fallow agricultural fields are being converted into simple cashew agroforestry interspersed with some trees of other species. Thus, the agroforestry agricultural intensification, instead of allowing the stabilization of the cultivated area, involves the destruction of areas. This is because when an area is converted to simple agroforestry, farmers look for new areas for cultivating agricultural crops, namely rice, peanuts, corn, etc. Only a few farmers intersperse their crop production with cashew plantations, and others prefer not to intersperse other crops with cashew plantations.

In developing countries, the collection of wood for fuel and the conversion of land covered by forests to the collection of wood for commercialization, fuel, and agricultural use led to high rates of deforestation (Field and Field, 2014). Changes that have taken place in Guinea-Bissau's soil are a consequence of land use predominantly associated with agricultural activities, charcoal production, timber exploitation, firewood for domestic use, and exploitation of African palmyra palm (Borassus aethiopum) to cover houses (Temudo and Cabral, 2017).

Deforestation and forest degradation are responsible for large part of the global greenhouse gases. Much of the debate on the mechanism for Reducing Emissions from Deforestation and Forest Degradation (REDD+) has focused on the effects of deforestation. Forests are more than carbon stocks and and the REDD+ mechanism must be concerned not only with reducing the effects of climate change, but also with the creation of socioeconomic structures for the sustainable management of forests (Faria et al., 2014). In Guinea-Bissau, as CNS producers begin to invest in new technologies, that is, increasing their CNS production costs, there will be a reduction in fires to clear the land
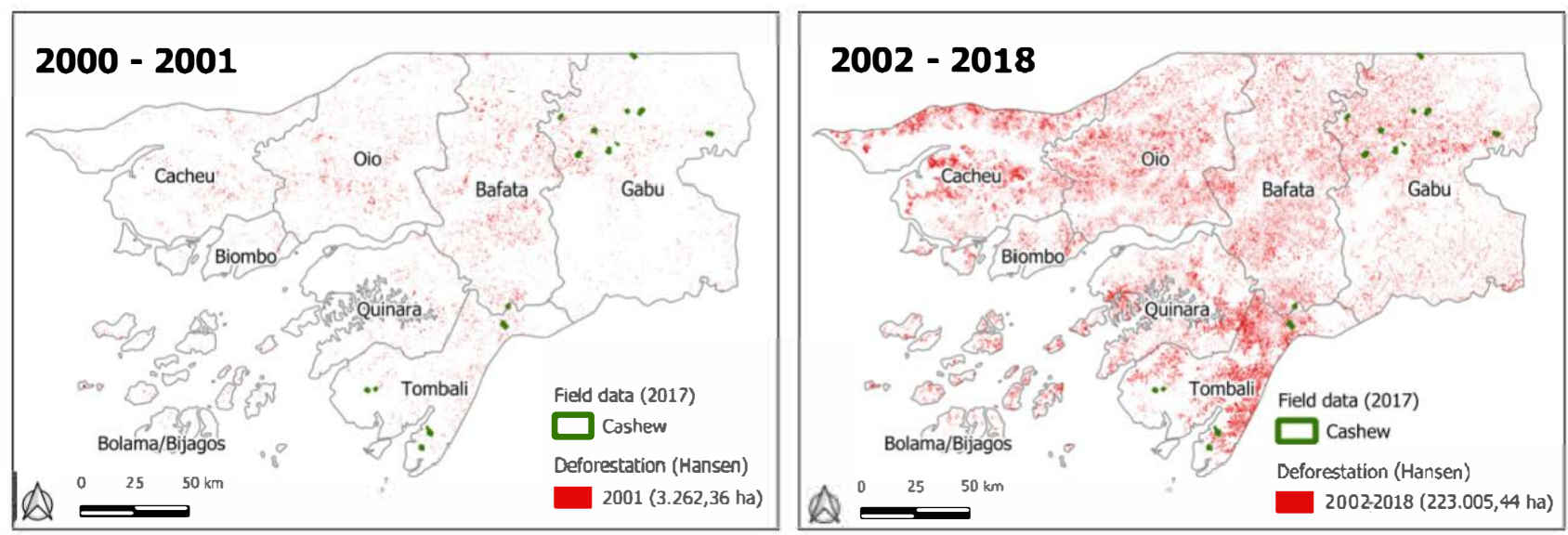

Figure 4 - Intensity of land occupation (2001 to 2018) in Guinea-Bissau.

Source: Prepared by the authors based on data from Global Forest Change (2013). 
for cashew orchards, new techniques to combat pests through biopesticides, increased productivity, etc.

Many developing countries may have a bright future if they are able to competently exploit their biodiversity through use of biotechnologies, both to increase biomass production and to increase the spectrum of products derived from it (Sachs, 2008). In Guinea-Bissau, the exploitation of natural resources requires control and costs to reduce environmental pollution.

According to Rivas (2014, p. 98), the cost in this case "is the reduction of pollution to a lower level so that there is little damage." There must be an optimum point of deforestation. Ecosystems provide important services for people's survival, as stated by Rivas (2014, p. 185), "ecosystem services can be defined as the contributions arising from the functioning of ecosystems, ecological characteristics, functions or processes that indirectly contribute to life and human well-being."

Forests have a direct use value, such as ecotourism; indirect use value, as protection of water bodies, soil, fire, and control of floods and microclimate; option value, as for discovering new drugs; and non-use or nonexistence value, as an intrinsic value, existence of nonhuman species, or preservation of cultural, religious and historical values (Motta, 2002). Therefore, forest protection is essential for sustainable development. It is also important to encourage the agencies with jurisdiction to reduce deforestation in the country. An incentive is something that attracts or alienates people and, somehow, leads to a change in their behavior (Field and Field, 2014).

Nonexclusive, sustainable, and sustained development is needed. Sustainable development fulfills the double ethical imperative of solidarity with present and future generations, and requires the explicit definition of criteria for social and environmental sustainability and economic viability (Sachs, 2008). In Guinea-Bissau, it is necessary to address the short-term emergencies linked to crisis management by reflecting on the medium- and long-term strategies. Both must be informed by the same vision of sustainable development that, on the one hand, offers the assessment criteria for the proposed policies and, on the other hand, through a broad social debate, gradually unfolds in a national project.

The transition to sustainable development begins with crisis management, which requires an immediate paradigm shift, moving from growth financed by the inflow of external resources and the accumulation of external debt to a growth based on the mobilization of internal resources, employing people to work in activities with import content (Sachs, 2008). It is important to encourage the internal consumption of goods and services, in such a way economic growth, employment, and income for families can be generated, with the purpose of reducing agricultural exploitation as the main source of income for families with fewer financial resources.

All citizens must have equal access to assistance programs for disabled people, for mothers and children, for older adults, aimed at compensating for natural or physical inequities. Compensatory social policies financed by income redistribution should go further and include unemployment benefits, a task that is practically impossible in countries where only a small minority is employed in the organized sector and where open unemployment is far less significant than underemployment. The population as a whole should have equal opportunities to access public services, such as education, health protection, and housing. Education, for instance, is essential for local and human development, due to its intrinsic value, as it contributes to cultural awakening, awareness, understanding of human rights, increasing adaptability and a sense of autonomy as well as self-confidence and self-esteem.

\section{Conclusions}

The environmental impacts associated with the intensification of deforestation in Guinea-Bissau can be attributed to the expansion of the main agricultural products, such as cashew, rice, peanuts and, more recently, to the illegal logging of wood for commercialization destined for the Chinese market.

CNSE accounts for an average of $8.9 \%$ of the country's GDP. This economic activity has at least four macroeconomic impacts:

- the commercialization of CNS injects liquidity for producers, intermediaries and exporters;

- it affects the price levels of other goods and services due to the high propensity of economic actors to consume;

- it is the main source of foreign exchange revenue due to exports;

- it is an important source of tax revenue due to taxes collected during the commercialization, until it is exported.

According to the interviewees, most of them believe that the Government does not contribute to public policies for the sustainable development of the cashew sector; non-governmental institutions (NGOs) are the ones that contribute the most with investments for the growth and sustainable development of the cashew sector. It is a consensus among the interviewees that, in recent years, CNSP has been increasing, but this increase is due to the growth of new agricultural areas. They also believe that the decrease in the production of other crops in favor of CNSP is encouraged by the CNS price in the domestic market due to the demand and its price abroad.

With the use of geoprocessing techniques, the authors verified that the country has been significantly increasing the occupation of land use in all regions, mainly in southern areas, close to the borders with the Republic of Guinea and in northern areas, where the borders with the Republic of Senegal-of Senegal are located. One of the main causes of deforestation is the population increase, which somewhat boosts agricultural production and the illegal timber trade, especially in the border regions.

Investment incentives are needed for large-scale CNS processing, which is a product with greater added value. This process must have a sustainable structure with less environmental impact. It is necessary to 
promote the diversification of the economy in all sectors, in accordance with the social and economic potential of the country.

\section{Acknowledgments}

The authors are grateful to everyone who directly or indirectly contributed to the performance of this research; interviewed experts and the anonymous reviewers of the manuscript. In particular, the Brazilian Government, the Graduate Program in Environmental Sciences (PPGCASA) of Universidade Federal do Amazonas, and the National Council for Scientific and Technological Development $(\mathrm{CNPq})$ for financing the Master's Degree scholarship of the main author.

\section{Contribution of authors:}

Seca, A.I.: Conceptualization, Methodology, Validation, Formal Analysis, Investigation, Resources, Data Curation, Writing - Original Draft. Pereira, H.S: Conceptualization, Methodology, Review \& Editing, Supervision. Pedroza, S.C.: Methodology, Formal Analysis, Investigation, Review \& Editing.

\section{References}

Agência Nacional de Caju - ANCA. 2013. Relatório sobre campanha de comercialização e exportação de castanha de caju. ANCA.

Anselmo, J.L., 2013. Matemática dos tributos. Cepam, São Paulo (Accessed February 6, 2020) at: http://www.educacaofiscal.sp.gov.br/contents/ Matem\%C3\%A1tica\%20dos\%20Tributos.pdf.

Arvanitis, Y.; Roffarello, L.M.; Ié, I., 2017. African economic outlook. PEA, v. 16, (4-266). https://doi.org/10.1787/19991029.

Balde, S., 2008. Buba-Quebo: corredor de desenvolvimento no sul da GuinéBissau. Dissertação, Mestrado em Estudos Africanos, Universidade Nova de Lisboa, Lisboa. Retrieved 2020-01-20, from https://repositorio.iscte-iul.pt/ handle/10071/748.

Banco de Portugal. 2020. Cambio (Accessed January 20, 2020) at: https://www. bportugal.pt/taxas-cambio.

Banque Centrale des Etats de L'Afrique de L'ouest - BCEAO. Entrepôt de données economiques et financiéres (Accessed January 12, 2019) at: https:// edenpub.bceao.int/.

Bello, D.O.; Ahoton, L.E.; Saidou, A.; Akponikpè, I.P.B.; Ezin, V.A.; Balogoun, I.; Aho, N., 2017. Climate change and cashew (Anacardium occidentale L.) productivity in Benin (West Africa): perceptions and endogenous measures of adaptation. Ciências Biológicas e Químicas, v. 11, (3), 1-23. https://doi. org/10.4314/ijbcs.v11i3.1.

Cabral, A.I.R.; Costa, L.F., 2017. Land cover changes and landscape pattern dynamics in Senegal and Guinea Bissau borderland. Applied Geography, v. 82, 115-128. https://doi.org/10.1016/j.apgeog.2017.03.010.

Catarino, L.; Menezes, Y.; Sardinha, R., 2015. Cashew cultivation in GuineaBissau - risks and challenges of the success of a cash crop. Scientia Agricola, v. 72, (5), 459-467. http://dx.doi.org/10.1590/0103-9016-2014-0369.

Cateia, J.V.; Veloso, G.O.; Feistel, P.R., 2018. Determinants of Guinea-Bissau cashew exports (1986-2011): an analysis under the Bergstrand gravity model. Revista da Economia e Sociologia Rural, v. 56, (4), 583-604. https://doi. org/10.1590/1234-56781806-94790560403.

Danfá, S.; Silva, A.M.; Mello, C.R.; Coelho, G.; Viola, M.R.; Ávila, L.F., 2009. Distribuição espacial de valores prováveis de precipitação pluvial para períodos quinzenais, em Guiné-Bissau. Revista Brasileira de Engenharia Agrícola Ambiental, v. 15, (1), 67-74. https://doi.org/10.1590/S1415-43662011000100010.

Deforestation Statistics. 2020. Primary forest loss and tree cover loss: GuinéBissau (Accessed March 15, 2019) at: https://rainforests.mongabay.com/ deforestation/archive/GuineaBissau.htm.
Defries, R.S.; Rudel, T.; Uriarte, M.; Hansen, M., 2010. Deforestation driven by urban population growth and agricultural trade in the twenty-first century. Nature Geoscience, v. 3, 178-181. https://doi.org/10.1038/ngeo756

Dendena, B.; Corsi, S., 2014. Cashew, from seed to market: a review. Agronomy for Sustainable Development, v. 34, 753-772. https://doi.org/10.1007/s13593014-0240-7.

Doggart, N. 2020. Agriculture is the main driver of deforestation in Tanzania. Environmental Research, v. 15, 034028. https://doi.org/10.1088/1748-9326/ ab6b35

Dormann, C.F.; Elith, J.; Bacher, S.; Buchmann, C.; Carl, G.; Carré, G.; Marquéz, J.R.G.; Gruber, B.; Lafourcade, B.; Leitão, P.J.; Münkemüller, T.; McClean, C.; Osborne, P.E.; Reineking, B.; Schröder, B.; Skidmore, A.K.; Zurell, D.; Lautenbach, S., 2013. Collinearity: a review of methods to deal with it and a simulation study evaluating their performance. Ecography, v. 36, (1), 27-46. https://doi.org/10.1111/j.1600-0587.2012.07348.x.

Elakkiya, E.; Sivara, P.; Vijayaprabhakar, A., 2017. Growth and Performance of Cashew Nut Production in India- An Analysis. International Journal of Current Microbiology and Applied Sciences, v. 6, (6), 1817-1823. https://doi. org/10.20546/ijcmas.2017.606.211.

FAOSTAT. 2020. Food and Agriculture Organization of the United Nations. Dados sobre produção, preço e exportação de castanha de caju. 2020 (Accessed November 10, 2019) at: http://countrystat.org/home.aspx?c=GNB\&tr=1.

Faria, M.L.; Ferreira, P.M.; Melo, J.B.; Vasconcelos, M.J., 2014. A social assessment of forest degradation in the "Cacheu mangroves natural park", Guinea-Bissau. Forest, v. 5, (12), 3327-3343. https://doi.org/10.3390/f5123327.

Field, B.C.; Field, M.K., 2014. Economia do meio ambiente. 6a ed. AMGH, Porto Alegre.

Food and Agriculture Organization - FAO. 2014. The impact of domestic and trade policies on the world cotton Market. FAO, (8), 1-45 (Accessed April 16, 2020) at: http://www.fao.org/3/a-j2731e.pdf.

Food and Agriculture Organization - FAO. 2020. Cashew nut (Accessed December 15, 2019) at: http://www.fao.org/3/X5043E/x5043E06.htm.

Fundo Monetário Internacional - FMI. 2015. Os custos da fragilidade na GuinéBissau: instabilidade política crônica (Accessed March 27, 2019) at: https://www. imf.org/external/lang/portuguese/pubs/ft/SCR/2015/cr15195p.pdf.

Fundo Monetário Internacional - FMI. 2017. Fundo Monetário Internacional. Relatório sobre: a economia do caju e o desenrolar da campanha de 2017. FMI, (20090), 1-62. 
Global Forest Change. 2013. Results from time-series analysis of Landsat images characterizing forest extent and change (Accessed March 15, 2020) at: https://earthenginepartners.appspot.com/science-2013-global-forest.

Henders, S.; Persson, U.M.; Kastner, T., 2015. Trading forests: land-use change and carbon emissions embodied in production and exports of forest-risk commodities. Environmental Research Letters, v. 10, (12), 125012. https:// orcid.org/0000-0001-7069-6734.

Jayathilake, H.M.; Prescott, G.; Carrasco, L.R.; Rao M.; Symes, W.S., 2020. Drivers of deforestation and degradation for 28 tropical conservation landscapes. Ambio, v. 50, 215-228. https://doi.org/10.1007/s13280-020-01325-9.

Li, J.; Alvarez, B.; Siwabessy, J.; Tran, M.; Huang, Z.; Przeslawski, R.; Radke, L.; Howard, R.; Nichol, S., 2017. Aplicação de floresta aleatória, modelo linear generalizado e seus métodos híbridos com técnicas geoestatísticas para contagem de dados: previsão da riqueza de espécies de esponjas. Environnmental Modelling e Software, v. 97, 112-129.

Martin, P.J.; Topper, C.P.; Bashiru, R.A.; Boma, F., De Waal, D.; Harries, H.C.; Kasuga, L.J.; Katanila, N.; Kikoka, L.P.; Lamboll, R.; Maddison, A.C.; Majule, A.E.; Masawe, P.A.; Millanzi, K.J.; Nathaniels, N.Q.; Shomari, S.H.; Sijaona, M.E.; Stathers, T., 1997. Cashew nut production in Tanzania: constraints and progress through integrated crop management. Journals \& Books, v. 16, (1), 5-14. https://doi.org/10.1016/S0261-2194(96)00067-1.

Medina, N., 2008. O ecossistema orizícola na Guiné-Bissau: principais constrangimentos à produção na zona i (regiões de Biombo, Cacheu e Oio) e perspectivas. Dissertation, Universidade Técnica de Lisboa. Retrieved 2019-01-04, from https://www.repository.utl.pt/bitstream/10400.5/1977/1/ TESEFINAL.pdf.

Ministério da Economia, Plano e Integração Regional - MEPIR. 2012. Governo de Guiné-Bissau. Plano e Enquadramento de Gestão Ambiental e Social. v. 1, $37 \mathrm{pp}$.

Motta, R.S., 2002. Estimativa do custo econômico do desmatamento na amazônia. IPEA. 2002 (Accessed November 3, 2018) at: http://repositorio.ipea. gov.br/handle/11058/2800.

Muteia, H., 2014. A importância das florestas para um mundo melhor. O País (Accessed February 12, 2019) at: http://www.fao.org/fileadmin/user_upload/ faoweb/lisbon/docs/O_Pa\%C3\%ADs_21_3_2014.pdf.

Novo, E.M.L.M.; Ponzoni, F.J., 2001. Introdução ao sensoriamento remoto (Accessed June 10, 2001) at: http://www.dpi.inpe.br/Miguel/AlunosPG/Jarvis/ SR_DPI7.pdf.

Observatory of Economic Complexity - OEC. 2020. Product trade (Accessed March 16, 2020) at: oec.world/en/profile/country/gnb/.

Ordway, E.M.; Asner, G.P.; Lambin, E.F., 2017. Deforestation risk due to commodity crop expansion in sub-Saharan Africa. Environmental Research Letters, v. 12, (4), 044015. https://doi.org/10.1088/1748-9326/aa6509.

Projeto de Prestação de Serviço de Extensão Rural - PER. 2019. Diversificação agrícola (consorciação). KAFO, 51 pp.
Rivas, A., 2014. Economia e serviços ambientais utilizando técnicas de preferencias declaradas. Ed. Universidade Federal de Amazonas, Manaus.

Rudel, T.K.; Defries, R.; Asner, G.P.; Laurance, W.F., 2009. Changing drivers of deforestation and new opportunities for conservation. Conservation Biology, v. 23, (6), 1396-1405. https://doi.org/10.1111/j.1523-1739.2009.01332.x

Sachs, I., 2008. Desenvolvimento includente, sustentável sustentado. Garamond, Rio de Janeiro.

Samate, A.I.S., 2018. Análise da cadeia produtiva de castanha de caju com ênfase no beneficiamento e comercialização da amêndoa em GuinéBissau. Dissertação, Programa da Pós-graduação em Administração e Desenvolvimento Rural, Universidade Federal de Pernambuco, Recife.

Silva, F.A.; Freitas, C.O.; Mattos, L.B., 2016. Volatilidade da taxa de câmbio e seus efeitos sobre o fluxo de comércio dos países da América do Sul. Economia Contemporânea, v. 20, (2), 229-249. http://dx.doi.org/10.1590/198055272022.

Temudo, M.P., 2009. A narrativa da degradação ambiental no Sul da GuinéBissau: uma desconstrução etnográfica. Etnográfica, v. 13, (2), 237-264. https:// doi.org/10.4000/etnografica.1341.

Temudo, M.P.; Abrantes, M., 2014. The Cashew Frontier in Guinea-Bissau, West Africa: Changing Landscapes and Livelihoods. Human Ecology, v. 42, 217-230. https://doi.org/10.1007/s10745-014-9641-0.

Temudo, M.P.; Cabral, A.I., 2017. The social dynamics of mangrove forests in guinea-bissau, west África. Human Ecology, v. 45, (1), 307-320. 2017. https:// doi.org/10.1007/s10745-017-9907-4.

Temudo, M.P.; Santos, S., 2017. Shifting environments in Eastern GuineaBissau, West Africa: The length of fallows in question. Wageningen Journal of Life Sciences, v. 80, 57-64. https://doi.org/10.1016/j.njas.2016.12.001

The Humanitarian Data Exchange. 2019 (Accessed December 28, 2019) at: https://data.humdata.org/.

United Nations Development Program - UNDP. 2019. Inequalities in human development in the 21st. Guiné-Bissau, 1-9 (Accessed May 22, 2020) at: http:// hdr.undp.org/sites/all/themes/hdr_theme/country-notes/GNB.pdf.

Vinuto, J., 2014. A amostragem em bola de neve na pesquisa qualitativa: um debate em aberto. Temáticas, v. 22, (44), 203-220. https://doi.org/10.20396/ tematicas.v22i44.10977.

Weinzettel, J.; Hertwich, E.G.; Peters, G.P.; Olsen, S.A.; Galli, A., 2013. Affluence drives the global displacement of land use. Global Environmental Change, v. 23, (2), 433-438. https://doi.org/10.1016/j.gloenvcha.2012.12.010

World Bank. 2020. Climate change (Accessed January 2, 2019) at: https:// climateknowledgeportal.worldbank.org/download-data.

World Bank. 2019. Development data (Accessed January 15, 2019) at: http:// databank.worldbank.org/data/home.aspx.

World Bank of Guinea-Bissau. 2019. Overview (Accessed January 10, 2020) at: https://www.worldbank.org/en/country/guineabissau/overview. 